\title{
Study of Bioreactor Landfill Cell Design Using Base Model
}

\author{
Akshay C. Chauhan ${ }^{1}$, Dr. Shashikant B. Kamble ${ }^{2}$, and Dr. Anurag Kandya ${ }^{3}$
}

\begin{abstract}
Landfill practices in India are turning to sustainable management of the municipal solid waste (MSW). The conventional landfill with no productivity is upgrading by the bioreactor landfill with the energy generation. This paper gives detailed comparative idea about the bioreactor landfill with the Leachate and Sewage circulation in to the municipal solid waste (MSW) using the prototyped base model. The domestic sewage circulation has been found an effective approach to the reactor. At the peak, Methane (CH4) concentration was noticed around $18,000 \mathrm{ppm}$ and $30,000 \mathrm{ppm}$ and average Methane (CH4) concentration was noted around $3777.77 \mathrm{ppm}$ and 21,666.66ppm for Leachate and Sewage Circulation respectively, which can productively used for domestic and small scaled industry purpose. The analysed chemical parameters like $\mathrm{pH}$, MLSS, MLVSS, Nitrate, BOD, COD of generated leachate in to the reactor were also reflecting the suitability of sewage circulation to the bioreactor landfill model.
\end{abstract}

Keywords - Bioreactor Landfill, Leachate, Sewage, Base Model.

\section{INTRODUCTION}

A rising quality of life, and high rates of resource consumption patterns have had a unintended and negative impact on the urban environment - generation of wastes far beyond the handling capacities of urban governments and agencies. Cities are now grappling with the problems of high volumes of waste, the costs involved, the disposal technologies and methodologies, and the impact of wastes on the local and global environment. Also when if we will focus on the scenario of the treatment of the sewage than During 2015,the estimated sewage generation in the country was 61754 MLD as against the developed sewage treatment capacity of 22963 MLD.[1]

Because of the hiatus in sewage treatment capacity, about

Akshay C. Chauhan1, Pandit Deendayal Petroleum University, Gandhinagar-382007 (Phone no.+91-9662269055, e-mail: chauhanakshay127@gmail.com, akshay.cmten15@sot.pdpu.ac.in)

Dr. Shashikant B. Kamble2, Scientist, National Environmental Engineering Research Institute(CSIR-NEERI), Mumbai-400018 (e-mail: sb_kamble@neeri.res.in)

Dr. Anurag Kandya3, Assistant Professor, Pandit Deendayal Petroleum University, Gandhinagar-382007 (e-mail: anurag.kandya@sot.pdpu.ac.in)
38791 MLD of untreated sewage (62\% of the total sewage) is discharged directly into nearby water bodies. The five states viz Maharashtra, Tamil Nadu, Uttar Pradesh, Delhi \& Gujarat account for approximately $50 \%$ of the total sewage generated in the country. Maharashtra alone accounts for $13 \%$ of the total sewage generation in the country. So it is very necessary to look upon it. [1]

But these problems have also provided a window of opportunity for cities to find solutions - involving the community and the private sector; involving innovative technologies and disposal methods; and involving behaviour changes and awareness rising. These issues have been amply demonstrated by good practices from many cities around the world. There is a need for a complete rethinking of "waste" - to analyze if waste is indeed waste. A rethinking that calls for "WASTE to become WEALTH REFUSE to become RESOURCE TRASH to become CASH"

The discipline associated with control of generation, storage, collection, transport or transfer, processing and disposal of solid waste materials in a way that best addresses the range of public health, conservation, economics, aesthetic, engineering and other environmental considerations is called as Solid Waste Management. The primary goal of solid waste management is reducing and eliminating adverse impacts of waste materials on human health and environment to support economic development and superior quality of life.

\section{A. .Integrated Solid Waste Management (ISWM)}

ISWM is a very popular term in the field of waste management. It is defined as the selection and use of appropriate management programs, technologies, and techniques to achieve particular waste management goals and objectives. [2] According to the U.S. Environmental Protection Agency (EPA), ISWA is composed of waste source reduction, recycling, waste combustion and landfills. [2].

\section{B. Waste Disposal}

Disposal is the ultimate fate of all solid wastes, be they residential wastes, semi-solid wastes from municipal and industrial treatment plants, incinerator residues, composts or other substances that have no further use to the society. Thus, land use planning becomes a primary determinant in the selection, design and operation of landfill operations. A modern sanitary landfill is a method of disposing solid waste without creating a nuisance and hazard to public health.[3] 
Generally, engineering principles are followed to confine the wastes to the smallest possible area, reduce them to the lowest particle volume by compaction at the site and cover them after each day's operation to reduce exposure to vermin. One of the most important functional elements of SWM, therefore, relates to the final use of the reclaimed land.[3].

\section{C.Types of Landfill}

1. Conventional Landfill / Sanitary Landfill

2. Bioreactor Landfill

\section{Conventional Landfill / Sanitary Landfill}

"Sanitary Landfill" call for the isolation of the land filled wastes from the environment until the wastes are rendered innocuous through the biological, chemical, and physical processes of nature.[4] Major differences between the various definitions are in the degree of isolation and means of accomplishing it, as well as in the requirements for monitoring and closing the fill and in maintaining the fill after its active life. In industrialized nations, the degree of isolation required usually is much more complete than would be practical in developing nations.[4]Not surprisingly, the means of accomplishing the high degree of isolation in developing nations are complex and expensive. In order to be designated a sanitary landfill, a disposal site must meet the following three general but basic conditions:

- Compaction of the wastes

- Daily covering of the wastes (with soil or other material) to remove them from the influence of the outside environment

Control and prevention of negative impacts on the public health and on the environment[4]

However, meeting all specific aspects may be technologically and economically impractical in many developing countries. Therefore, the short-term goal should be to meet the more important aspects to the extent possible under the existing set of technical and financial circumstances. The long-term goal should be to eventually meet all of the specific aspects of the design and operating conditions. [4] Only when a fill meets all of the specific conditions will all of the benefits associated with a sanitary landfill be realized. The most important condition is the prevention of negative impacts on public health and the environment.[4].

\section{Bioreactor Landfill}

Generates to rapidly transform and degrade organic waste the increase in waste degradation and stabilization is accomplished through the addition of liquid and air to enhance microbial process.[5]

\section{a. Bioreactor Landfill Technology}

Bioreactor technology accelerates the biological decomposition of food, green waste, paper and other organic wastes in a landfill by promoting conditions necessary for the microorganisms that degrade the waste.[5] The single most important factor in promoting waste decomposition is the moisture content of the waste. [5] Liquids must be added to the waste mass to obtain optimal moisture content, which ranges from 35 to 45 percent water by weight. Liquids that are added include: landfill leachate, gas condensate, water, storm water runoff, and wastewater treatment sludges. [5].

\section{b. Bioreactor Landfill Benefits}

- Accelerated waste stabilization. Stabilized landfills can be converted to other useful purposes years sooner with greater as surance of environmental safety[5]

- Recovery of 15 to 35 percent of landfill space as waste decomposes and is converted to gas extends the useful life of landfills, reducing the need to site new facilities [5]

- Expanded and concentrated production of methane gas favors beneficial gas use projects while decreasing greenhouse gas emissions over the life of the landfill[5]

- Leachate recirculation reduces leachate management costs while improving leachate quality[5]

- Provide an environmentally sound alternative to the land application of certain liquid wastes [5].

\section{c. Types Bioreactor Landfill Process}

Waste Management is evaluating four types of bioreactor Landfill Proces ses [5]

- Aerobic-Anaerobic

- Aerobic

- Anaerobic

- Facultative

\section{MAterials AND MethodOlOGY}

\section{A. Geosynthetic Clay Liners}

Geosynthetic Clay Liners (GCLs) are geotextile and bentonite composites (typically sodium bentonite sandwiched between two layers of geotextile) engineered for a variety of environmental containment applications.[6].

\section{B. Geomembrane HDPE Liners}

A Geomembrane is very low permeability synthetic membrane liner or barrier used with any geotechnical engineering related material so as to control fluid (or gas) migration in a human-made project, structure, or system.[6].

\section{Geotextile Membrane}

A permeable geosynthetic comprised solely of textiles. Geotextiles are used with foundation, soil, rock, earth, or any other geotechnical engineering-related material as an integral part of human-made project, structure, or system.[6]

The main aim of the bioreactor model is to study the degradation rate of the waste, leachate quantity and leachate concentration, Gas generation, its quantity and characteristics; these will be followed in the methodology. The prototyped base model of bioreactor landfill was established which was containing two chambers, one was for leachate circulation and one was for sewage circulation.

\section{Waste Collection}

The municipal solid waste consisting of Garden waste, Hotel 
waste, Stationary waste of around $20 \mathrm{~kg}$ was collected from the Dadar market of Mumbai. The waste was collected in the black garbage bags and kept in cool place just to maintain its physical and chemical properties. The waste was also containing the inorganic materials like plastics, tin canes etc. the ratio of organic to inorganic waste was 1:0.2, it means $80 \%$ organic waste and $20 \%$ inorganic waste composition was maintained.

\section{E. Feeding of Waste}

The waste of around $10 \mathrm{~kg}$ was feeded to each chamber. For the easy identification, let " $\mathrm{A}$ " indicate the leachate circulation chamber and "B" indicate the sewage circulation. The waste compacted by the rod by maintaining the base slope of the reactor. The reactor was placed where not much temperature difference occurs.

\section{F. Feeding ofleachate and sewage}

As the waste was implemented, the leachate generation was not found in A and B in initial 5 days, so we had taken 2 liters of the leachate from the dumping site and analyzed its characteristics like $\mathrm{pH}$, Nitrate, Biochemical Oxygen Demand (BOD), Chemical Oxygen Demand (COD), Mixed Liquor Suspended Solids (MLSS), Mixed Liquor Volatile Suspended Solids (MLVSS). The leachate of 1.5 Liters was feeded to the waste. Also at the same time the domestic sewage of 2 liters was collected and its characteristics were analyzed same as the leachate characteristics. The reactor kept closed to give an anaerobic condition to the waste and to collect the gas coming out of it.

\section{G. Analysis of generated Leachate for $A$ and $B$}

10 days after the leachate and sewage circulation, fresh leachate found in both the chamber A and B. As A was containing comparatively dry waste so the only $50 \mathrm{ml}$ of leachate got collected and from B $560 \mathrm{ml}$ of leachate got collected and analyzed. After collection of leachate from A and $\mathrm{B}$ the Gas was analyzed through biogas analyzer and collected in tedlar bags to measure its quantity. The gas collection and analysis was under taken at 10days, 20days and 25 days from the day of leachate and sewage circulation. The generated leachate and gas characteristics are discussed in the following results.

\section{RESULTS}

The characteristics and compositions of the particulates were counted as follow
TABLE I.

Leachate and Sewage Characteristics (Feeded)

\begin{tabular}{|c|c|c|c|}
\hline \multirow{2}{*}{$\mathrm{pH}$} & $\mathrm{A}$ & 8.41 & \\
\cline { 2 - 4 } & $\mathrm{B}$ & 7.44 & \\
\hline \multirow{2}{*}{ MLSS } & $\mathrm{A}$ & 6.7 & $\mathrm{Mg}$ \\
\cline { 2 - 4 } & $\mathrm{B}$ & 1.4 & $\mathrm{Mg}$ \\
\hline \multirow{2}{*}{ MLVSS } & $\mathrm{A}$ & 2.89 & $\mathrm{Mg}$ \\
\cline { 2 - 4 } & $\mathrm{B}$ & 0.75 & $\mathrm{Mg}$ \\
\hline \multirow{2}{*}{ Nitrate } & $\mathrm{A}$ & 12.59 & $\mathrm{mg} / \mathrm{lit}$ \\
\cline { 2 - 4 } & $\mathrm{B}$ & 21.22 & $\mathrm{mg} / \mathrm{lit}$ \\
\hline \multirow{2}{*}{$\mathrm{BOD}$} & $\mathrm{A}$ & 1904 & $\mathrm{mg} / \mathrm{lit}$ \\
\cline { 2 - 4 } & $\mathrm{B}$ & 638.4 & $\mathrm{mg} / \mathrm{lit}$ \\
\hline \multirow{2}{*}{$\mathrm{COD}$} & $\mathrm{A}$ & 60926 & $\mathrm{mg} / \mathrm{lit}$ \\
\cline { 2 - 4 } & $\mathrm{B}$ & 5623 & $\mathrm{mg} / \mathrm{lit}$ \\
\hline
\end{tabular}

TABLE II.

Leachate Characteristics (COLlected)

\begin{tabular}{|c|c|c|c|}
\hline \multirow{2}{*}{$\mathrm{pH}$} & $\mathrm{A}$ & 7.71 & \\
\cline { 2 - 4 } & $\mathrm{B}$ & 7.45 & \\
\hline \multirow{2}{*}{ MLSS } & $\mathrm{A}$ & 7.6 & $\mathrm{Mg}$ \\
\cline { 2 - 4 } & $\mathrm{B}$ & 6.5 & $\mathrm{Mg}$ \\
\hline \multirow{2}{*}{ MLVSS } & $\mathrm{A}$ & 2.5 & $\mathrm{Mg}$ \\
\cline { 2 - 4 } & $\mathrm{B}$ & 1.69 & $\mathrm{Mg}$ \\
\hline \multirow{2}{*}{ Nitrate } & $\mathrm{A}$ & 12.93 & $\mathrm{mg} / \mathrm{lit}$ \\
\cline { 2 - 4 } & $\mathrm{B}$ & 22.29 & $\mathrm{mg} / \mathrm{lit}$ \\
\hline \multirow{2}{*}{$\mathrm{BOD}$} & $\mathrm{A}$ & 1422.4 & $\mathrm{mg} / \mathrm{lit}$ \\
\cline { 2 - 4 } & $\mathrm{B}$ & 1371.6 & $\mathrm{mg} / \mathrm{lit}$ \\
\hline \multirow{2}{*}{ COD } & $\mathrm{A}$ & 40698 & $\mathrm{mg} / \mathrm{lit}$ \\
\cline { 2 - 4 } & $\mathrm{B}$ & 4526 & $\mathrm{mg} / \mathrm{lit}$ \\
\hline
\end{tabular}

The recorded data were for $60 \mathrm{~min}$. for 10,20 and 25 days. and the data logging time interval in analyzer was $30 \mathrm{sec}$. so total 120 data sets were there for each day. The methane $(\mathrm{CH} 4)$ collection and analys is results were found as follow.

Methane ( $\mathrm{CH} 4)$ generation is the major element in the bioreactor landfill which always taken in to account for the energy utilization. After 25 days average $\mathrm{CH} 4$ for A was noted as $0.61 \%$ and average $\mathrm{CH} 4$ for $\mathrm{B}$ was noted as $1.35 \%$ in the reactor.

TABLE III.

Average \% OF CH4 IN A \& B

\begin{tabular}{|c|c|c|c|}
\hline Days & 10 & 20 & 25 \\
\hline $\begin{array}{c}\text { Average \% } \\
(\mathrm{A})\end{array}$ & 0.108 & 0.288 & 0.613 \\
\hline $\begin{array}{c}\text { Average \% } \\
(\mathrm{B})\end{array}$ & 0.007 & 0.138 & 1.359 \\
\hline
\end{tabular}




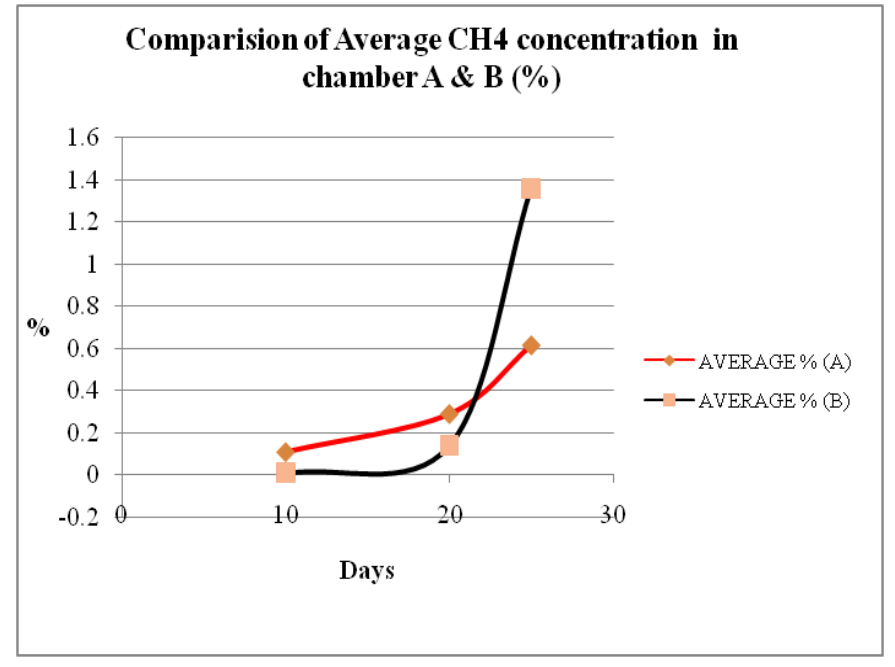

Fig. 2 Comparision of Average $\mathrm{CH} 4$ concentration in chamber A \& B (\%)

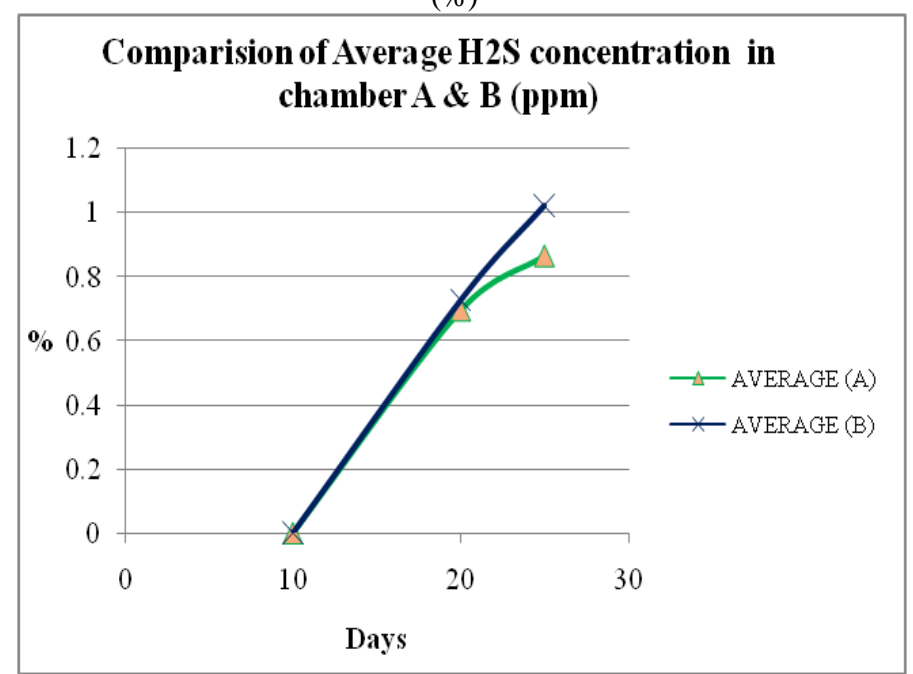

Fig. 3 Comparision of Average H2S concentration in chamber A \& B (ppm)

\section{CONCLUSION}

From this comparative study between leachate and sewage circulation to the municipal solid waste we can conclude that the sewage circulation is more effective and productive in context of energy generation. The sewage water can be efficiently use for the faster decomposition of waste instead of leachate. also its if we will look upon the chemical characteristics of the leachate and sewage, the sewage is containing less Ultimate BOD and COD content than leachate so it is most suitable approach to protect the ground water.

\section{ACKNOWLEDGMENT}

Authors thank Dr. H.B Raghuvendra, Director, School of Technology and Dr. Debasis Sarkar, Head, Department of Civil Engineering, Pandit Deendayal Petroleum University for the encouragements and Guidance, and authors would like to thank CSIR-NEERI, Mumbai for their help and support.

\section{REFERENCES}

[1] ENVIS Centre on Hygiene, Sanitation, Sewage Treatment Systems and

Technology, http://www.sulabhenvis.nic.in/Database/ST ST_wastewater_2090.asp $\mathrm{x}$

[2] https://www.thebalance.com/an-introduction-to-solid-wastemanagement -2878102

[3] Management of municipal solid waste, T.V Ramachandra, Center for ecological sciences, Indian institute of science, Bangalore, pg. No 81

[4] http://www.unep.or.jp/ietc/publications/spc/solid_waste_managemen t/Vol_I/20_21-Part3_Section-Chapter14-rev.pdf

[5] https://www.epa.gov/landfills/bioreactorlandfillshttps://www.epa.gov/sites/production/files/201603/documents/geosyn.pdf 